\title{
A Search for Snail-Related Answers to Explain Differences in Response of Schistosoma mansoni to Praziquantel Treatment among Responding and Persistent Hotspot Villages along the Kenyan Shore of Lake Victoria
}

\author{
Martin W. Mutuku, ${ }^{1,2 \star}$ Martina R. Laidemitt, ${ }^{3}$ Brianna R. Beechler, ${ }^{4}$ Ibrahim N. Mwangi, ${ }^{1}$ Fredrick O. Otiato, ${ }^{5}$ Eric L. Agola, ${ }^{1}$ \\ Horace Ochanda, ${ }^{2}$ Bishoy Kamel, ${ }^{3}$ Gerald M. Mkoji, ${ }^{1}$ Michelle L. Steinauer, ${ }^{6}$ and Eric S. Loker ${ }^{3}$ \\ ${ }^{1}$ Centre for Biotechnology Research and Development, Kenya Medical Research Institute, Nairobi, Kenya; ${ }^{2}$ School of Biological Sciences, \\ College of Biological and Physical Sciences, University of Nairobi, Nairobi, Kenya; ${ }^{3}$ Department of Biology, Center for Evolutionary and \\ Theoretical Immunology, Museum of Southwestern Biology, Parasitology Division, University of New Mexico, Albuquerque, \\ New Mexico; ${ }^{4}$ Department of Biomedical Sciences, College of Veterinary Medicine, Oregon State University, Corvallis, \\ Oregon; ${ }^{5}$ Influenza Surveillance Program, Centers for Disease Control and Prevention, Nairobi, Kenya; ${ }^{6}$ Department of Basic \\ Medical Sciences, Western University of Health Sciences, Lebanon, Oregon
}

\begin{abstract}
Following a 4-year annual praziquantel (PZQ) treatment campaign, the resulting prevalence of Schistosoma mansoni was seen to differ among individual villages along the Kenyan shore of Lake Victoria. We have investigated possible inherent differences in snail-related aspects of transmission among such 10 villages, including six persistent hotspot (PHS) villages ( $\leq 30 \%$ reduction in prevalence following repeated treatments) located along the west-facing shore of the lake and four PZQ-responding (RESP) villages (>30\% prevalence reduction following repeated treatment) along the Winam Gulf. When taking into account all sampling sites, times, and water hyacinth presence/absence, shorelineassociated Biomphalaria sudanica from PHS and RESP villages did not differ in relative abundance or prevalence of $S$. mansoni infection. Water hyacinth intrusions were associated with increased $B$. sudanica abundance. The deeper water snail Biomphalaria choanomphala was significantly more abundant in the PHS villages, and prevalence of S. mansoni among villages both before and after control was positively correlated with $B$. choanomphala abundance. Worm recoveries from sentinel mice did not differ between PHS and RESP villages, and abundance of non-schistosome trematode species was not associated with S. mansoni abundance. Biomphalaria choanomphala provides an alternative, deepwater mode of transmission that may favor greater persistence of $S$. mansoni in PHS villages. As we found evidence for ongoing S. mansoni transmission in all 10 villages, we conclude that conditions conducive for transmission and reinfection occur ubiquitously. This argues for an integrated, basin-wide plan for schistosomiasis control to counteract rapid reinfections facilitated by large snail populations and movements of infected people around the lake.
\end{abstract}

\section{INTRODUCTION}

One of the most prevalent and persistent of the world's neglected tropical diseases is human schistosomiasis. ${ }^{1}$ There is currently considerable momentum to bring schistosomiasis under control and to proceed to elimination efforts. ${ }^{2-4}$ An essential weapon in the elimination of schistosomiasis is the drug praziquantel ( $P Z Q)$, which has been used extensively in a variety of control programs and has considerably reduced prevalence and intensity of infection. ${ }^{5}$ There is also a growing appreciation for the need for integrated control programs taking into account sanitation, provision of safe water, education, and acknowledging the fundamental role played by freshwater snails as vectors of the disease. ${ }^{6,7}$ The persistent success of schistosome parasites is owed substantially to their molluscan hosts, which support the prolific production of human-infective cercariae and that often exist in huge populations across a variety of freshwater habitats.

Africa harbors $90+\%$ of the global burden of Schistosoma mansoni. ${ }^{8}$ In Kenya, there are three taxa of Biomphalaria snails that perpetuate transmission: 1) Biomphalaria pfeifferi, whose distribution includes tributaries feeding Lake Victoria, and in small impoundments and both seasonal and perennial streams throughout the country, except in the tropical lowland belt along the coast; 2) Biomphalaria sudanica, mainly found

\footnotetext{
*Address correspondence to Martin W. Mutuku, Centre for Biotechnology Research and Development, Kenya Medical Research Institute, P.O. Box 54840-00200, Nairobi, Kenya. E-mail: mmutuku@ kemri.org
}

along the shores of Lake Victoria and Lake Jipe and their surrounding swamps; and 3) Biomphalaria choanomphala, a deeper water inhabitant of Lake Victoria.,10 The latter two taxa are likely members of the same species and are frequently referred to as ecophenotypes or ecomorphs. ${ }^{11-13}$

Prevalence of intestinal schistosomiasis in Kenya is highest (> 50\%) in the Mwea Irrigation Scheme in central Kenya and in the Lake Victoria basin in western Kenya. ${ }^{14}$ Recent studies assessing the prevalence of S. mansoni infection in school children in the lake basin reported overall prevalences of $60.5 \%$ and $69 \%$, with villages on lake islands having 2 -fold higher prevalence rates than mainland villages. ${ }^{15,16}$ Schools closer to the lake also had higher prevalence rates than those further from the lake. ${ }^{15}$ Both higher prevalences and likelihood of reinfection following treatment would logically be associated with more frequent contact with lake water containing infected snails. $^{17}$

Several chemotherapy-based initiatives have been undertaken to control schistosomiasis in the Lake Victoria region. ${ }^{17-20}$ Among them, the Schistosomiasis Consortium for Operational Research and Evaluation (SCORE) project implemented school-based and village-wide mass drug administration (MDA) in varying treatment regimens over four consecutive years (2011-2015) for 150 Kenyan villages situated on or near the eastern shore of Lake Victoria. ${ }^{17}$ Villages were randomized with respect to six different treatment strategies (study arms), which involved combinations of school-based or community-wide treatments, with three study arms receiving annual treatment and three receiving treatment twice over a 4-year period. Regardless of study 
arm or age group of treated individuals, using spatial scan statistics, a persistent hotspot area was identified in western Siaya County comprising west-facing villages along the open waters of the lake. ${ }^{17}$ Prevalence and intensity of infection did not decrease as much as it did in areas outside of the persistent hotspot area, the latter including villages along the more protected shores of the Winam Gulf. ${ }^{17}$ Although this study could not clearly identify factors driving persistence of infection at hotspots, it reported an association between schistosome persistence and vegetation density (as measured by remote sensing), indicating a potential role for snail ecology.

Particular locations where the prevalence or intensity of schistosome infection does not fall to expected levels despite well-implemented, multiyear, MDA have been termed persistent hotspots (PHS), in contrast to responding (RESP) villages in which intensity and prevalence decline as expected. Why do some villages fail to respond to multi-annual treatment with PZQ? Several explanations can be offered, including variability in efficacy of PZQ among worm populations in different areas, levels of sanitation or availability of toilets, extent of drug coverage or compliance, availability of safe water supplies, extent of water contact, defecation behavior, or the extent to which they experience population movements such as resulting from fishing activities or proximity to ferry landings. ${ }^{19,21-24}$

Conditions associated with snail vectors may also vary considerably, including the nature of the snail species present, their abundance and local compatibility with schistosomes, longevity of infected snails and the rate at which they produce cercariae, and their patterns of distribution relative to water contact sites and anthropogenic disturbance. ${ }^{21,25-32}$ Shoreline and bottom conditions can also play important roles in efficacy of transmission. ${ }^{9,21,23,31,33}$

In addition to the shoreline-associated vegetation effects noted by Wiegand et al. ${ }^{17}$ as a possible factor associated with PHS, the dramatic presence and movements of large floating mats of the introduced water hyacinth, Eichhornia crassipes, are other factors in lake ecology that cannot be overlooked. Hyacinths have been suggested to provide a suitable environment for schistosome-susceptible snails and to facilitate their movements around the lake. ${ }^{34}$ Plummer noted that significantly more $B$. sudanica were recovered from experimental enclosures containing hyacinths than control enclosures lacking them, and Ofulla et al. also concluded that $B$. sudanica was significantly associated with hyacinths in the Nyanza Gulf (now referred to as Winam Gulf), Kenya. ${ }^{35,36}$ The Winam Gulf is one of the areas of the lake most affected by hyacinths, and four of the 10 villages we investigated are found on the gulf. ${ }^{37}$ Although hyacinth mats seem to favor snails in the short term, it has been noted that longer term residence of hyacinth mats may be harmful to snails because of deficits in light penetration, water circulation, and oxygen availability, the latter because of decomposing hyacinths. ${ }^{35}$

Here, we focus on the relationship of Biomphalaria snails to PZQ-based control efforts for S. mansoni in and around the Kenyan shoreline of Lake Victoria, one of the world's major hyperendemic foci of human schistosomiasis. On the request of the SCORE program, during the 2 years immediately following the cessation of their MDA project, on four separate occasions, we surveyed Biomphalaria populations and their schistosome infection rates adjacent to 10 villages along the
Kenyan shore of Lake Victoria with different degrees of responsiveness to treatment. In each of two collecting sites per village, we took note of the general condition of the habitat and searched for snails in shoreline-associated and deeper water habitats in the lake, as well as in smaller habitats adjacent to the lake. Building on the results of Wiegand et al., ${ }^{17}$ we investigated the hypotheses that PHS and RESP villages differ with respect to the species of vector snails present, relative snail abundance, likelihood that the snails are infected with schistosomes or other trematodes, and numbers of cercariae in the water as measured by infection rates of sentinel mice. All of these factors could contribute to persistently high prevalence in the face of control operations.

\section{MATERIALS AND METHODS}

Study sites. The study involved 10 villages along the shores of Lake Victoria, western Kenya (Figure 1), that were part of the Wiegand et al. ${ }^{17}$ study already mentioned. The villages had annual school-based MDA for four consecutive years (Table 1). Following one of the definitions of Kittur et al., ${ }^{38}$ six of the villages (Minya, Agok, Migiro, Miyandhe, Kanyibok, and Usenge) were PHS, locations where the absolute change in S. mansoni prevalence from the beginning of the control program to the end was $\leq 30 \%$. By contrast, for the four remaining villages (Kotieno, Seka Dok, St. Douglas Weta, and Mumbo) recorded a drop in prevalence $>30 \%$ and are considered RESP villages. In each village, two shoreline habitats were identified where there was evidence of human-water contact activities, and these were established as our sampling sites. Each of the 20 sampling sites was visited four times (April 2016, August 2016, January 2017, and May 2017).

Snail sampling. Two methods were used to collect snails from each of the 20 designated sampling sites: scooping from the shore and dredging from a boat. From the shore, two experienced collectors from our team scooped snails for 30 minutes per sampling site using long-handled scoops (steel sieve with a mesh size of $2 \times 2 \mathrm{~mm}$, supported on an iron frame). Shoreline habitats were typical for Lake Victoria consisting of emergent and submerged vegetation that was swept by scoops for snails. Snails were also collected offshore by passing a dredge $(0.75 \mathrm{~m}$ long and $0.4 \mathrm{~m}$ wide with an attached sieve, $2 \times 2-\mathrm{mm}$ mesh size) along the bottom. At each sampling site, dredge hauls covering a combined length of $150 \mathrm{~m}$ was made, beginning at $1 \mathrm{~m}$ depth and extending perpendicular to the shore to $10 \mathrm{~m}$ depth. Live snails were picked from the dredged material. All snails were taken to the laboratory at Kenya Medical Research Institute (KEMRI), Center for Global Health Research, Kisumu, where they were sorted into species based on shell morphology characteristics, using standard taxonomic identification keys, counted, and screened. ${ }^{39}$

Snail screening. Each snail was placed in an individual well of a 24-well plastic culture plate containing $1 \mathrm{~mL}$ of aged dechlorinated tap water. The plate was placed in indirect sunlight for 2 hours between 10:00 and 13:00 hours. Individual wells were then examined with the aid of a dissecting microscope for the presence of cercariae. Using standard identification keys, cercariae were identified to basic taxonomic groups. ${ }^{40}$ Non-shedding snails were maintained in the laboratory for 4 weeks and screened again to enable detection of snails that harbored prepatent infections at the time of initial collection. ${ }^{30}$ Some cercariae were further identified with molecular methods 


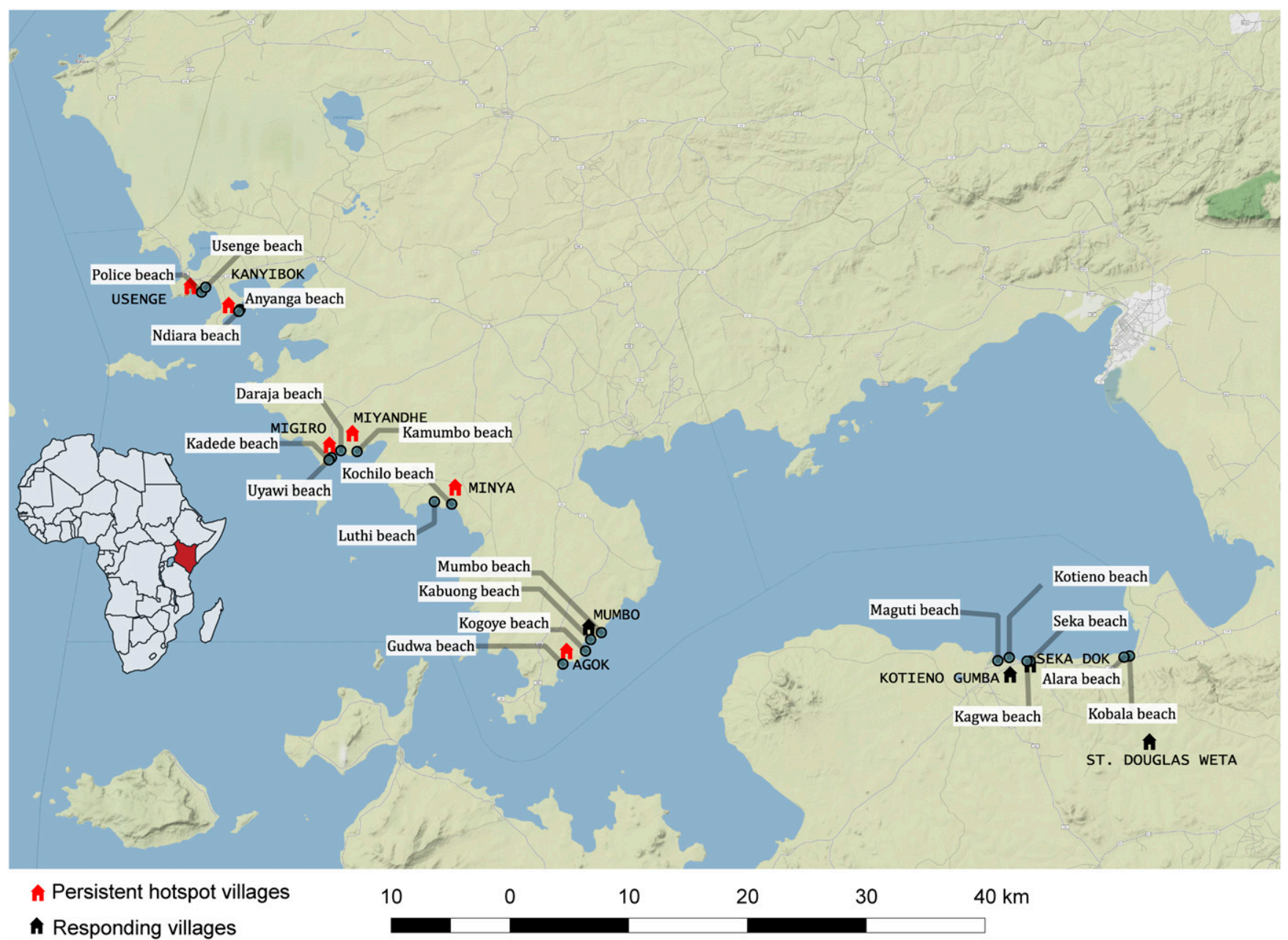

FIGURE 1. Map showing position of study villages along the shore of Lake Victoria, Kenya. The map was constructed using the QGIS version 2.18.22 and 3.2.1; the base map layer was added from the standard terrain tiles provided from http://maps.stamen.com through the OpenLayers function. The tiles are ${ }^{\circledR}$ Stamen Design (San Francisco, CA), under a creative commons attribution (CC BY 3.0) license. The data for the locations were obtained manually using cellular phone global positioning system (GPS) functionality according to the WGS1984 mercator projection. This figure appears in color at www.ajtmh.org.

as parts of another study. ${ }^{41}$ In addition, samples of mammalian schistosome cercariae recovered from $B$. sudanica (each sample consisting of four cercariae) were extracted (QIAamp DNA Micro Kit, Valencia, CA, to elution volume of $45 \mu \mathrm{L}$ ), and primers for the mitochondrial nicotinamide adenine dinucleotide dehydrogenase subunit 5 gene (nad5) were used for amplification, following which the bands were visualized on a gel (302 bp expected band size for S. mansoni and 800 bp for the related schistosome Schistosoma rodhaini) as a check for the identity of the schistosome recovered. ${ }^{27}$

TABLE 1

Schistosoma mansoni prevalence in schools within the study villages showing response to praziquantel treatment following 4 years of mass drug administration

\begin{tabular}{|c|c|c|c|c|c|c|}
\hline School & $\begin{array}{c}\text { Prevalence (\%) year } 1 \\
(2011)\end{array}$ & $\begin{array}{c}\text { Prevalence }(\%) \text { year } 2 \\
(2012)\end{array}$ & $\begin{array}{c}\text { Prevalence }(\%) \text { year } 3 \\
(2013)\end{array}$ & $\begin{array}{c}\text { Prevalence }(\%) \text { year } 4 \\
(2014)\end{array}$ & $\begin{array}{c}\text { Prevalence }(\%) \text { year } 5 \\
(2015)\end{array}$ & $\begin{array}{l}\text { Absolute prevalence change } \\
\text { (year } 1 \text { minus year } 5 \text { as \%) }\end{array}$ \\
\hline \multicolumn{7}{|c|}{ Persistent hotspot villages } \\
\hline Minya & $68.6(n=97)$ & $77(n=100)$ & $75(n=97)$ & $74(n=92)$ & $82(n=97)$ & +13.4 \\
\hline Agok & $60.5(n=99)$ & $59.8(n=93)$ & $60.2(n=97)$ & $67(n=86)$ & $39(n=91)$ & -21.5 \\
\hline Migiro & $69.4(n=100)$ & $76.7(n=94)$ & $49.2(n=87)$ & $72(n=87)$ & $48(n=88)$ & -21.4 \\
\hline Miyandhe & $78.6(n=86)$ & $70.5(n=91)$ & $71.4(n=87)$ & $73.5(n=92)$ & $54(n=94)$ & -24.6 \\
\hline Kanyibok & $91.8(n=100)$ & $93(n=96)$ & $83.7(n=98)$ & $84(n=94)$ & $83(n=100)$ & -8.8 \\
\hline Usenge & $69.4(n=100)$ & $68(n=100)$ & $65(n=100)$ & $46.5(n=100)$ & $65(n=100)$ & -4.4 \\
\hline \multicolumn{7}{|l|}{ Responding villages } \\
\hline Kotieno & $52.9(n=87)$ & $40.9(n=92)$ & $19(n=93)$ & $16(n=84)$ & $12(n=88)$ & -40.9 \\
\hline Seka Dok & $81.6(n=100)$ & $73.2(n=97)$ & $55.8(n=91)$ & $48(n=90)$ & $19(n=96)$ & -62.6 \\
\hline St. Douglas Weta & $55.2(n=100)$ & $27.4(n=94)$ & $24(n=93)$ & $19(n=87)$ & $19(n=91)$ & -36.2 \\
\hline Mumbo & $57.7(n=77)$ & $30(n=74)$ & $11.5(n=78)$ & $15.6(n=79)$ & $5.5(n=77)$ & -52.5 \\
\hline
\end{tabular}

Data acquired from and shown with permission of the SCORE project. Sample sizes shown in parentheses. 
Sentinel mice exposures. Mice were exposed to lake water at each nearshore sampling site in floating cages that ensured the mice were exposed to a depth of no more than $5 \mathrm{~mm}$. Each cage was made from a plastic container measuring $20 \times 14 \times 7 \mathrm{~cm}$ with the bottom of the container replaced with wire mesh with openings measuring $5 \times 5 \mathrm{~mm}$. Styrofoam blocks were attached to the plastic container to ensure the cage floated at the desired position. Lids of the containers were dark to provide shading and were perforated with 5-mm-diameter holes to allow air circulation. The abdomen of each mouse was shaved to facilitate cercariae penetration. For each of the shoreline sampling sites, five cages, each with two mice, were tethered adjacent to locations where snails were collected (total of 20 mice per village per sampling time). Mice were in contact with the water for 3 hours (11:00-14:00 hours), an interval when shedding of cercariae by $S$. mansoni-infected snails is expected to be at its peak. ${ }^{42}$ Previous experience under lakeside conditions indicated that a 3-hour period of exposure did not jeopardize survival of the mice, which was confirmed by the high survival rates of the mice retrieved. Mice from each sampling site were then marked with an identifying ear tag and maintained together until perfused at 8 weeks postexposure. Recovered worms were counted and tabulated with respect to village, sampling site, and sampling time. ${ }^{43}$

Ethics statement. All experiments involving mice were approved by Institutional Animal Care and Use Committees at the KEMRI (Protocol KEMRI/ACUC/03.10.15) and at the University of New Mexico (Animal Welfare Assurance \# D1600565 (A4023-01, expiration August 29, 2021). All protocols and practices for the handling and manipulation of mice were in accordance with the guidelines of the American Veterinary Medical Association for humane treatment of laboratory animals.

Statistical analysis. To determine if PHS sites differed from RESP sites in snail-related factors, we compared them with respect to relative abundance of each snail $(B$. sudanica or $B$. choanomphala), the prevalence of infected snails, and the number of adult schistosome worms collected from the sentinel mice (as a measure of the force of infection). Collection sites were nested into village and were compared across the four time points. Because of the potential effects of large rafts of floating water hyacinths that temporarily occupy some sites, we included the presence or absence of hyacinths in the models.

Snail relative abundance. To determine whether relative abundance of either $B$. sudanica or $B$. choanomphala differed between PHS and RESP villages, between sites with hyacinths and no hyacinths, or over time, we performed generalized linear mixed models in $\mathrm{R}$ using the package glmmTMB (R Core Team, Vienna, Austria), with the random effect of village and using the family negative binomial 1 (nbinom1). ${ }^{44}$ Before settling on this model structure, we also explored a model that included a nested random effect of sample site within village, but the model fit was not significantly better (ANOVA, $P>0.05$ ), so we report the reduced model of only village as a random effect.

Formula: glmmTMB (Abundance of either snail $\sim$ Responder/ Not + Hyacinth $Y / N$ + time point + (1 $\mid$ School), family = nbinom1 $($ link $=\log )$ )

Prevalence of infected snails. To determine whether the likelihood of detecting an infected snail was different in an RESP versus PHS village, or in sites with and without hyacinths, we performed a generalized linear mixed model using $\mathrm{R}$ with the packages ImerTest and Ime4 (R Core Team, Vienna, Austria) with the random effect of village and the family of binomial (logit link). ${ }^{45}$ We also included the offset term of number of snails found, rescaled to be on the same scale as the binomial variables by dividing by two SDs. ${ }^{46}$ This is because there is a strong positive correlation between the likelihood of finding an infected snail and the total number of snails found (est $=0.592 \pm 0.148, P=0.00005$, statistics reported from the same model as described previously but with total number of snails found included as a main effect rather than an offset). We analyzed only data for $B$. sudanica because the number of infected $B$. choanomphala was prohibitively small.

Formula: glmer (S. mansoni presence $Y / N \sim$ responder/not + hyacinth $Y / N+(1 \mid$ time point) + (offset (rescaled total sudanica count)) + (1| school), family = binomial (link = "logit"))

Sentinel mice. To evaluate whether infection prevalence in the sentinel mice differed between PHS and RESP villages, between sites with and without hyacinths, and between time points, we performed a generalized linear mixed model in $R$ using the package glmmTMB with a random effect of village and family of negative binomial 1 . We also included the term of total snails found at each site to account for snail relative abundance; however, this variable was rescaled by dividing by two SDs to place it on the same scale as the binomial variables.

Formula: glmmTMB (total number of schistosomes in mice $\sim$ responder/not + time + total biomphalaria snails + (1 $\mid$ village), family = nbinom1 $($ link $=\log )$ )

We also evaluated whether the likelihood of finding a schistosome-positive sentinel mouse differed between PHS and RESP villages, between sites with and without hyacinths, and between time points. The only difference between this model and the one described previously is that the dependent variable is binomial (infected mouse found or not), rather than the burden within the infected mouse. For this, we used a model structure similar to the prevalence of infected snails. We performed a generalized linear mixed model with family of binomial (link = logit) and the random effect of village. Once again, we accounted for the total number of snails collected but rescaled it to be on the same scale as the binomial variables. $^{46}$

Formula: glmer (S. mansoni presence in mice $Y / N \sim$ responder/not + hyacinth $\mathrm{Y} / \mathrm{N}+$ (1| time point) + (offset (rescaled total biomphalaria count $))+(1 \mid$ village $)$, family = binomial (link = "logit"))

Correlation of human prevalence and snail density. To determine if the abundance of snails at a particular site was associated with schistosome infection rates in humans, we correlated the total number of snails collected at a village (summed between collecting sites and all four time points) with both the initial and the final prevalence in humans at the corresponding village using Pearson's correlation in GraphPad Prism 7.0 (San Diego, CA). We performed separate analyses for each snail species.

Biodiversity. To assess whether the likelihood of detecting a schistosome-infected $B$. sudanica at a site correlated with the presence of other digenetic trematodes in the snails, we included each of four commonly collected cercarial types (echinostome, strigeid, xiphidiocercariae, and amphistome) as a main effect in the same model as described earlier in the prevalence of infected snails. 
Formula: glmer $(S$. mansoni presence $Y / N \sim$ responder/ not + hyacinth $Y / N+$ amphistomes $Y / N+$ xiphido $Y / N$, echinostomes $Y / N$, strigieds $Y / N+(1 \mid$ time point) + (offset (rescaled total sudanica count)) + (1| village), family = binomial (link = “logit”)).

\section{RESULTS}

Descriptive overview. A total of 12,156 snails $(10,249$ $B$. sudanica and 1,907 B. choanomphala) were collected from the study sites during four collection periods (Table 2, Figure 2). No B. pfeifferi were found in the lake habitats sampled. We also searched small streams or impoundments near the villages and found them to be muddy, prone to drying, and without Biomphalaria snails. At some times and collecting sites, hyacinth mats covered the water surface and were so dense as to preclude dredging (Figure 2). Biomphalaria sudanica was recovered along the shoreline from all 20 sampling locations and $B$. choanomphala was dredged from deeper water at all 12 sampling locations in PHS villages, whereas Mumbo was the only RESP village from which B. choanomphala was found (Table 2). Of note is that Mumbo is located closer to the PHS villages than the remaining three RESP villages (Figure 1). Biomphalaria choanomphala was also sometimes found while scooping from shoreline collecting sites in three PHS locations, Kanyibok, Migiro, and Usenge. At Usenge Beach, the shoreline B. choanomphala population persisted for at least 5 months on submerged vegetation along with another snail customarily recovered from deeper water, Gabbiella humerosa. Fifteen meters away, in a patch of emergent vegetation, $B$. sudanica (but not $B$. choanomphala) was found. Biomphalaria choanomphala was also occasionally recovered from the shore intermingled with $B$. sudanica, as at the Anyanga Beach sampling site at Kanyibok.
Hyacinth mats were noted during three of the collective total of 48 total visits $(6.25 \%)$ we paid to PHS sampling sites, and two of these times precluded dredging at such sites (Figure 1). Hyacinth mats were found at 11 of 32 collective visits (34.3\%) at RESP sites, and five of these times precluded dredging.

Snail relative abundance. Overall, we collected far more $B$. sudanica than $B$. choanomphala (Table 2, Figure 2). However, it should be noted that because our collecting methods differed for each snail taxon, these numbers are not directly comparable (e.g., there is not necessarily a larger population of $B$. sudanica than $B$. choanomphala in the lake). The relative abundance of snails was highly variable among sites and collection times. For instance, at Miyandhe, one of the PHS villages, with its rocky, wave-swept lakeshore habitat, few snails were recovered relative to all the other villages. It was not unusual for snails to increase or decrease several fold between collection time points at the same habitats (Figure 2).

In Lake Victoria, B. sudanica is considered a more important intermediate host of $S$. mansoni than is $B$. choanomphala because $B$. sudanica with its shallow water habitat use is more likely to contact miracidia from human feces deposited along the shore. Thus, we predicted that snail-driven differences between PHS and RESP sites would be reflected in this species. However, we found that PHS sites did not contain more $B$. sudanica snails than RESP sites $(\beta=-0.0664, \mathrm{SE}=0.4603$, $P=0.8854$, Figure 3A). We note, however, that the three PHS villages (Minya, Kanyibok, and Usenge) with the highest residual prevalence of $S$. mansoni are also the three villages with the highest overall counts of Biomphalaria snails. Biomphalaria sudanica density was positively associated with the presence of hyacinths $(\beta=0.7704, \mathrm{SE}=0.2980, P=0.0097$, Figure 4) and the collecting time point $(\beta=0.37912$, SE = $0.09532, P<0.0001)$.

In contrast to the $B$. sudanica results, $B$. choanomphala was more abundant at PHS sites (Figure 3B) compared with RESP

TABLE 2

The 20 sampling sites and their GPS coordinates, total number of Biomphalaria sudanica and Biomphalaria choanomphala collected from each site, and the number of each species positive for Schistosoma mansoni

\begin{tabular}{|c|c|c|c|c|c|c|c|}
\hline Village & Habitat & Latitude & Longitude & B. sudanica & $\begin{array}{l}\text { No. of snails (+) } \\
\text { for S. mansoni }\end{array}$ & B. choanomphala & $\begin{array}{l}\text { No. of snails (+) } \\
\text { for S. mansoni }\end{array}$ \\
\hline \multicolumn{8}{|c|}{ Persistent hotspot villages } \\
\hline \multirow[t]{2}{*}{ Minya } & Kochilo Beach & $00^{\circ} 14^{\prime} 10.96^{\prime \prime S}$ & $034^{\circ} 14^{\prime} 45.79^{\prime \prime} \mathrm{E}$ & 522 & 0 & 96 & 0 \\
\hline & Luthi Beach & $00^{\circ} 14^{\prime} 04.58^{\prime \prime S}$ & $034^{\circ} 13^{\prime} 58.74^{\prime \prime} \mathrm{E}$ & 758 & 1 & 282 & 0 \\
\hline \multirow[t]{2}{*}{ Agok } & Gudwa Beach & $00^{\circ} 21^{\prime} 26.52^{\prime \prime} \mathrm{S}$ & $034^{\circ} 19^{\prime} 48.37^{\prime \prime} \mathrm{E}$ & 209 & 1 & 238 & 2 \\
\hline & Kogoye Beach & $00^{\circ} 20^{\prime} 51.94^{\prime \prime} \mathrm{S}$ & $034^{\circ} 20^{\prime} 74.32^{\prime \prime} \mathrm{E}$ & 220 & 6 & 85 & 0 \\
\hline \multirow[t]{2}{*}{ Migiro } & Uyawi Beach & $00^{\circ} 12^{\prime} 18.58^{\prime \prime S}$ & $034^{\circ} 09^{\prime} 18.36^{\prime \prime} \mathrm{E}$ & 728 & 1 & 89 & 0 \\
\hline & Kadede Beach & $00^{\circ} 12^{\prime} 12.09^{\prime \prime S}$ & $034^{\circ} 09^{\prime} 11.74^{\prime \prime} \mathrm{E}$ & 132 & 0 & 100 & 0 \\
\hline \multirow[t]{2}{*}{ Miyandhe } & Kamumbo Beach & $00^{\circ} 11^{\prime} 49.04^{\prime \prime S}$ & $034^{\circ} 10^{\prime} 28.17^{\prime \prime} \mathrm{E}$ & 48 & 0 & 15 & 0 \\
\hline & Daraja Beach & $00^{\circ} 11^{\prime} 46.65^{\prime \prime S}$ & $034^{\circ} 09^{\prime} 44.11^{\prime \prime} \mathrm{E}$ & 103 & 0 & 71 & 0 \\
\hline \multirow[t]{2}{*}{ Kanyibok } & Anyanga Beach & $00^{\circ} 05^{\prime} 22.49^{\prime \prime S}$ & $034^{\circ} 05^{\prime} 09.34^{\prime \prime} \mathrm{E}$ & 897 & 28 & 380 & 1 \\
\hline & Ndiara Beach & $00^{\circ} 05^{\prime} 27.33^{\prime \prime} \mathrm{S}$ & $034^{\circ} 05^{\prime} 06.24^{\prime \prime} \mathrm{E}$ & 407 & 0 & 161 & 0 \\
\hline \multirow[t]{2}{*}{ Usenge } & Police Beach & $00^{\circ} 04^{\prime} 34.80^{\prime \prime} \mathrm{S}$ & $034^{\circ} 03^{\prime} 24.74^{\prime \prime} \mathrm{E}$ & 833 & 19 & 4 & 0 \\
\hline & Usenge Beach & $00^{\circ} 04^{\prime} 21.49^{\prime \prime} \mathrm{S}$ & $034^{\circ} 03^{\prime} 35.84^{\prime \prime} \mathrm{E}$ & 489 & 4 & 292 & 0 \\
\hline \multicolumn{8}{|c|}{ B. sudanica 60/5,346 (1.12\%), B. choanomphala 3/1,813 (0.17\%) } \\
\hline \multicolumn{8}{|l|}{ Responding villages } \\
\hline \multirow[t]{2}{*}{ Kotieno } & Kotieno Beach & $00^{\circ} 21^{\prime} 09.07^{\prime \prime} \mathrm{S}$ & $034^{\circ} 40^{\prime} 03.52^{\prime \prime} \mathrm{E}$ & 674 & 2 & 0 & 0 \\
\hline & Maguti Beach & $00^{\circ} 21^{\prime} 17.57^{\prime \prime} \mathrm{S}$ & $034^{\circ} 39^{\prime} 32.50^{\prime \prime} \mathrm{E}$ & 649 & 16 & 0 & 0 \\
\hline \multirow[t]{2}{*}{ Seka Dok } & Seka Beach & $00^{\circ} 21^{\prime} 18.58^{\prime \prime S}$ & $034^{\circ} 40^{\prime} 59.95^{\prime \prime} \mathrm{E}$ & 462 & 2 & 0 & 0 \\
\hline & Kagwa Beach & $00^{\circ} 21^{\prime} 19^{\prime \prime S}$ & $034^{\circ} 40^{\prime} 52.12^{\prime \prime} \mathrm{E}$ & 834 & 1 & 0 & 0 \\
\hline \multirow{2}{*}{ St. Douglas Weta } & Kobala Beach & $00^{\circ} 21^{\prime} 05^{\prime \prime} \mathrm{S}$ & $034^{\circ} 45^{\prime} 31.21^{\prime \prime} \mathrm{E}$ & 735 & 0 & 0 & 0 \\
\hline & Alara Beach & $00^{\circ} 21^{\prime} 08^{\prime \prime} \mathrm{S}$ & $034^{\circ} 45^{\prime} 16.01^{\prime \prime} \mathrm{E}$ & 584 & 0 & 0 & 0 \\
\hline \multirow[t]{2}{*}{ Mumbo } & Kabuong Beach & $0^{\circ} 20^{\prime} 20.06^{\prime \prime} \mathrm{S}$ & $034^{\circ} 21^{\prime} 04.09^{\prime \prime} \mathrm{E}$ & 576 & 1 & 93 & 0 \\
\hline & Mumbo Beach & $0^{\circ} 20^{\prime} 0.99^{\prime \prime} \mathrm{S}$ & $034^{\circ} 21^{\prime} 33.03^{\prime \prime} \mathrm{E}$ & 389 & 1 & 1 & 0 \\
\hline \multicolumn{8}{|c|}{ B. sudanica $23 / 4,903(0.47 \%)$, B. choanomphala 0/94 (0\%) } \\
\hline
\end{tabular}




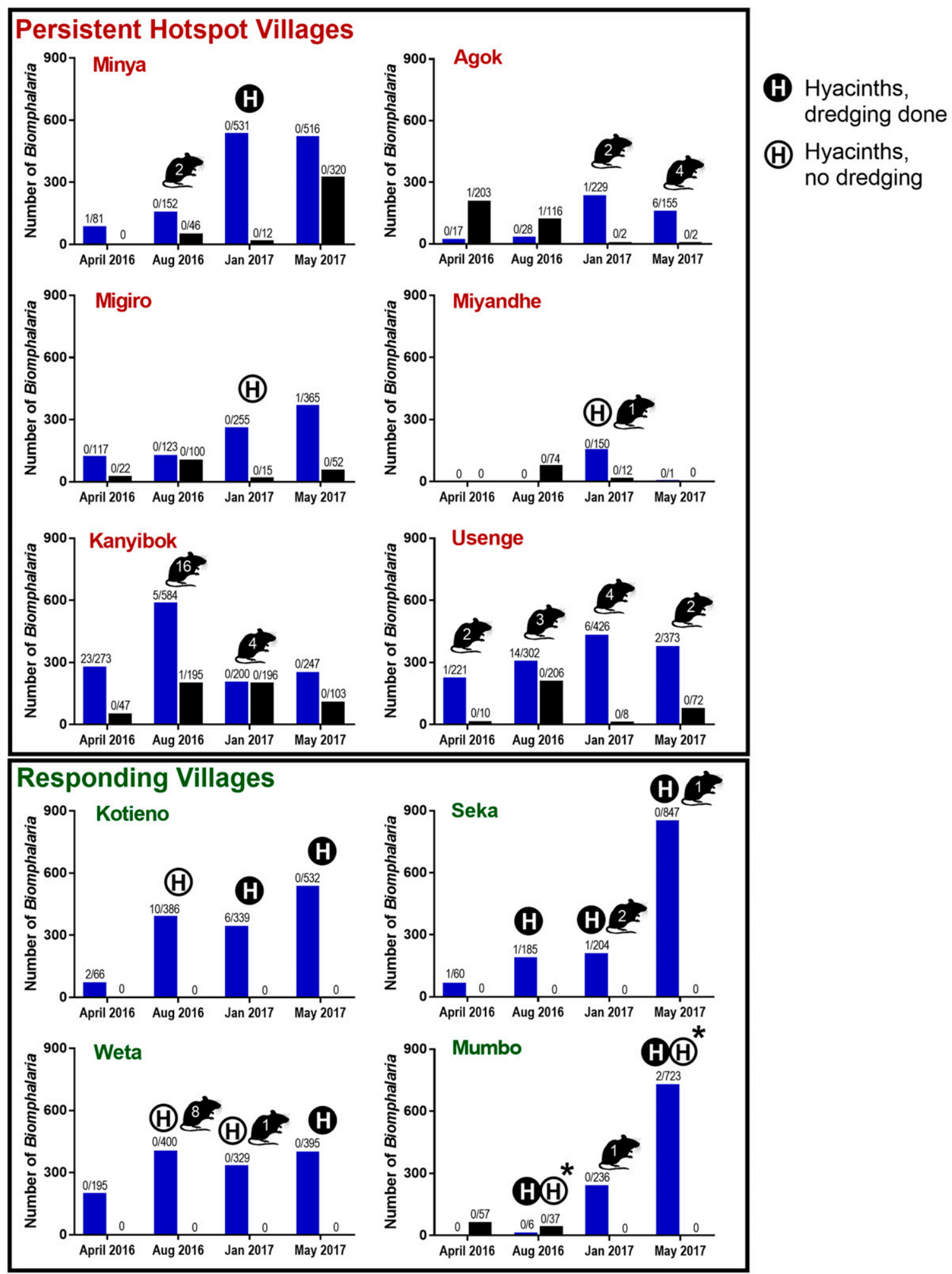

FIGURE 2. Number of Biomphalaria sudanica (blue bars) and Biomphalaria choanomphala (black bars) collected at each of the four sampling times (April and August 2016, January and May 2017) from the six persistent hotspot villages on the top vs. the four responding villages on the bottom. Snail numbers are summed between collection sites at a village. Numbers over bars indicate number of snails infected with Schistosoma mansoni shedders/total number of snails found. Numbers shown within mouse figures represent the number of worms recovered from sentinel mice at that time point (summed across mice and collection sites at that village). An $\mathrm{H}$ in a closed circle indicates hyacinths were present and dredging was carried out. An $\mathrm{H}$ in an open circle indicates hyacinths were present, but dredging could not be carried out. An asterisk (*) indicates Kabuong Beach was dredged but not Mumbo Beach. This figure appears in color at www.ajtmh.org. 

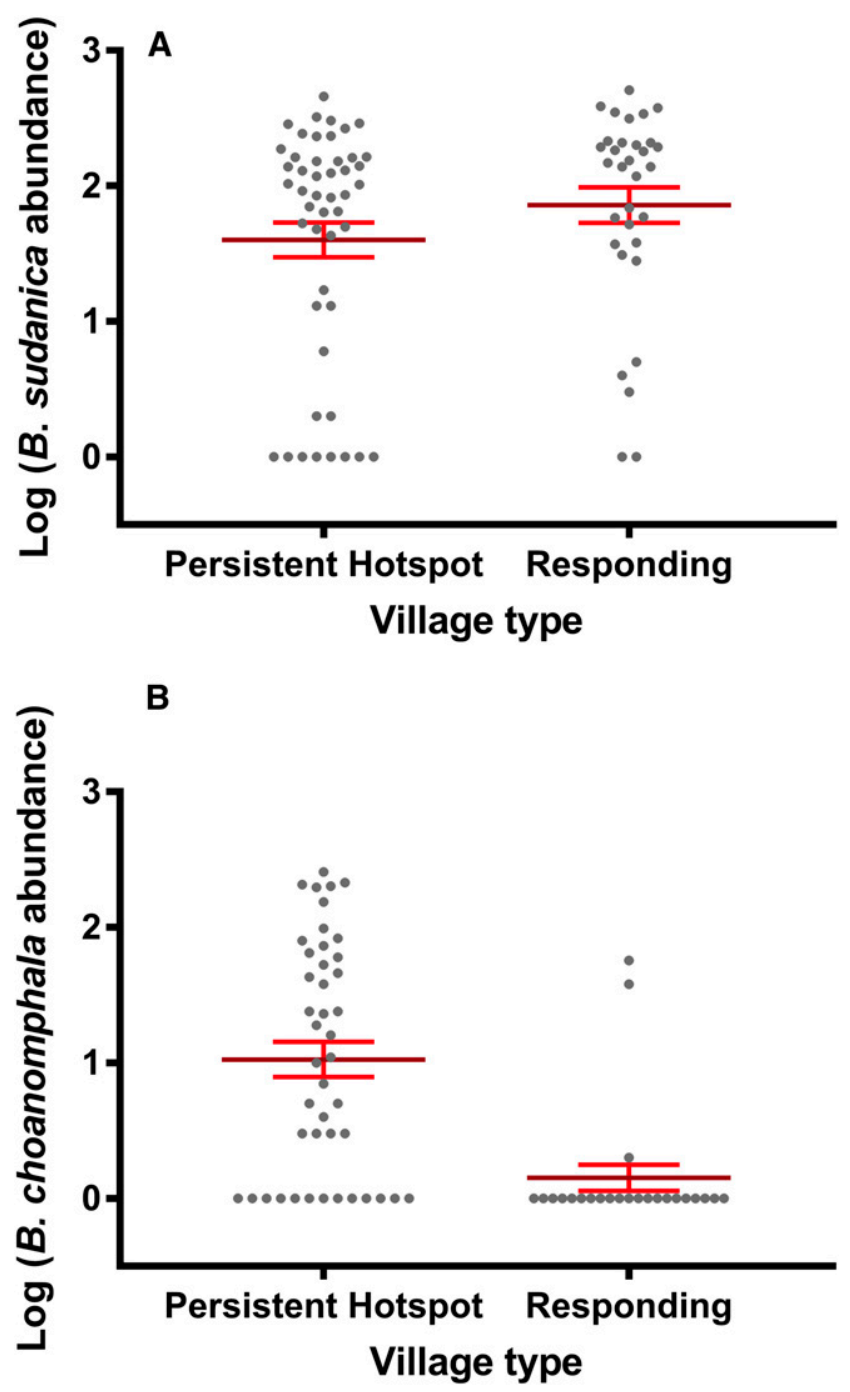

FIGURE 3. Relative abundance of Biomphalaria snails at persistent hotspot and responding sites of Lake Victoria in Kenya. (A). Persistent hotspot sites did not contain more Biomphalaria sudanica snails than responding sites when time point, village, and hyacinths were taken into account. (B). Biomphalaria choanomphala was far more abundant at persistent hotspot sites compared with responding sites $(P=$ 0.0091). Error bars indicate standard error of the mean. This figure appears in color at www.ajtmh.org.

sites $(\beta=-2.1644, \mathrm{SE}=0.6975, P=0.0091)$ and the presence of hyacinths and time point were not significantly associated with $B$. choanomphala density. Thus, results of the snail analysis indicated that only the deepwater taxon, B. choanomphala, differed between PHS and RESP sites. The other novel finding was that $B$. sudanica abundance was positively associated with the hyacinths.

Prevalence of infected snails. The overall number of positive snails and prevalence for $S$. mansoni recovered among all 10 villages examined were higher for $B$. sudanica $(83 / 10,249,0.81 \%)$ than for $B$. choanomphala $(3 / 1,907$, $0.16 \%)$. Although few $B$. choanomphala were found positive for S. mansoni, all came from PHS villages. For B. sudanica, the total number of $S$. mansoni-infected snails and overall prevalence was higher in PHS villages $(60 / 5,346,1.12 \%)$ than from RESP villages $(23 / 4,903,0.47 \%)$. As a check on the identity of schistosome cercariae recovered, we amplified

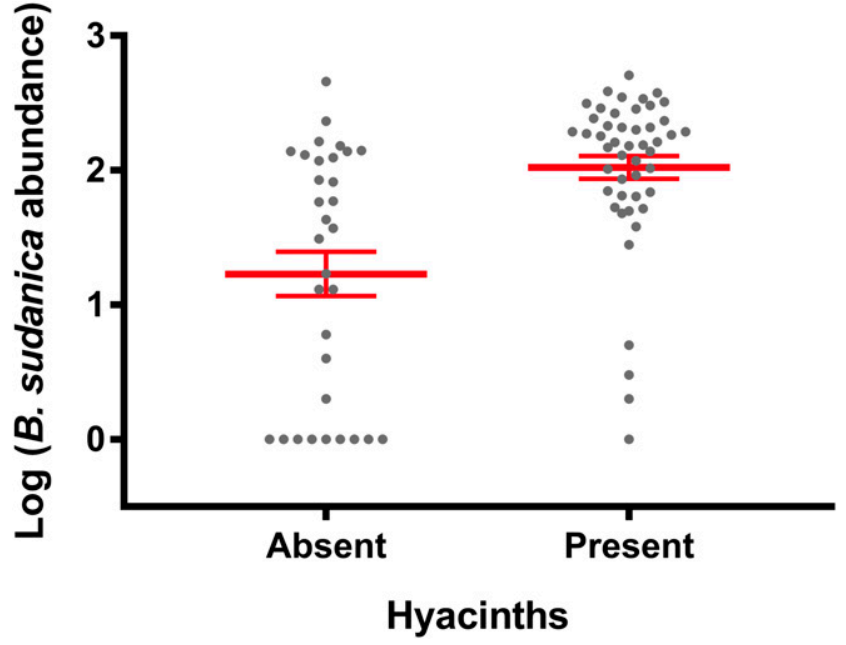

FIGURE 4. The number of Biomphalaria sudanica collected was greater when hyacinths were present than when hyacinths were not present $(P=0.00973)$. The presence of hyacinths did not influence Biomphalaria choanomphala abundance (not shown). Error bars indicate standard error of the mean. This figure appears in color at www.ajtmh.org.

the nad5 gene from cercariae from 20 different positive snails, five from each of the time points, and representing several beach sites where schistosome cercariae were found. ${ }^{27}$ All 20 samples were verified as S. mansoni based on nad5 band size, with one sample (Maguti Beach) exhibiting a double infection with both $S$. mansoni and S. rodhaini.

The distribution of $S$. mansoni infections among snails from the different villages is difficult to succinctly characterize. Two of the PHS villages with the highest residual post-treatment prevalences of S. mansoni in children, Kanyibok and Usenge, had the highest overall prevalence of positive snails $(1.57 \%$ and $1.42 \%$, respectively (Table 2 , Figure 2 ). From each locality though, most of these infections were found in a single collection raising the possibility they might have originated from one or a few human contamination events. Also, we found few shedders in Minya and Migiro, and none in Miyandhe, all PHS villages, whereas Kotieno, an RESP village, yielded the third most shedding snails, many of which were also found at a single time point. Ten of 24 sampling times (41.7\%) from PHS villages yielded positive snails, whereas seven of 16 sampling times $(43.8 \%)$ from RESP villages yielded snails positive for $S$. mansoni. Consequently, the number of $B$. sudanica infected with S. mansoni did not differ between PHS and RESP sites when time point, hyacinths, and village were all taken into account. There was a negative relationship that approached statistical significance between the number of infected snails collected and the presence of hyacinths at a site $(\beta=-0.12362$, $\mathrm{SE}=0.07186, P=0.0854$ ), a point considered further in the discussion.

Sentinel mice. Worm recoveries from sentinel mice (Figure 2) were low (53 worms recovered, or 0.066 worms per mouse, or 0.022 worms/mouse/hour of exposure). The greatest number of worms acquired by a single mouse was seven. Of the total number of worms recovered, 40 (75.5\%) were from PHS villages (0.083 worms/mouse), whereas $13(24.5 \%)$ were from RESP villages (0.041 worms/mouse). Although the total number of adult schistosomes collected from mice caged in PHS sites was greater than those caged 
in RESP sites, there was no statistical difference between them when village, hyacinths, and time point were considered (Figure 5, $\beta=-0.36479, \mathrm{SE}=0.5720, P=0.5237$ ). Examination of the viscera of positive sentinel mice revealed only the presence of S. mansoni eggs; no S. rodhaini eggs were found.

Correlation between snail abundance and human prevalence. Total number of $B$. sudanica collected at a village was not significantly correlated with $S$. mansoni prevalence in humans (Figure 6) either before or after the drug treatment intervention (before: Pearson $r=-0.0369, P=0.460$; after: Pearson $r=-0.009, P=0.49$ ). However, there was a strong correlation between the number of $B$. choanomphala collected at a village with $S$. mansoni prevalence in humans at the village (Figure 7) both before and after MDA (before: Pearson $r=$ $0.587, r^{2}=0.345, P=0.037$; after: Pearson $r=0.9034, r^{2}=$ $0.816, P=0.0002)$.

Infection of $B$. sudanica with other digenetic trematodes. In all 10 villages, the number of trematode infections other than S. mansoni observed from $B$. sudanica (Supplemental Table 1) exceeded those of $S$. mansoni (totals of 241 and 83, respectively). In PHS villages, 60 of 184 trematode infections were of S. mansoni (32\%), whereas in RESP villages, 23 of 150 (15\%) were of $S$. mansoni. Overall prevalence of trematode infections including S. mansoni was similar between PHS and RESP villages (3.5\% and $3.1 \%$, respectively). Echinostomes were the most abundant non-S. mansoni infections with 112 snails infected from the 10 study villages. We did not observe any snails to have double infections (e.g., to be simultaneously shedding two different kinds of cercariae). Although S. mansoni infections were consistently outnumbered by the aggregate totals of all other digenetic trematode infections, there were no statistical associations between the number of snails infected with S. mansoni and any of the other trematode species measured with the model used.

With respect to having high overall total trematode prevalence, three villages stood out from the rest, the two PHS villages Kanyibok and Usenge and the one RESP village

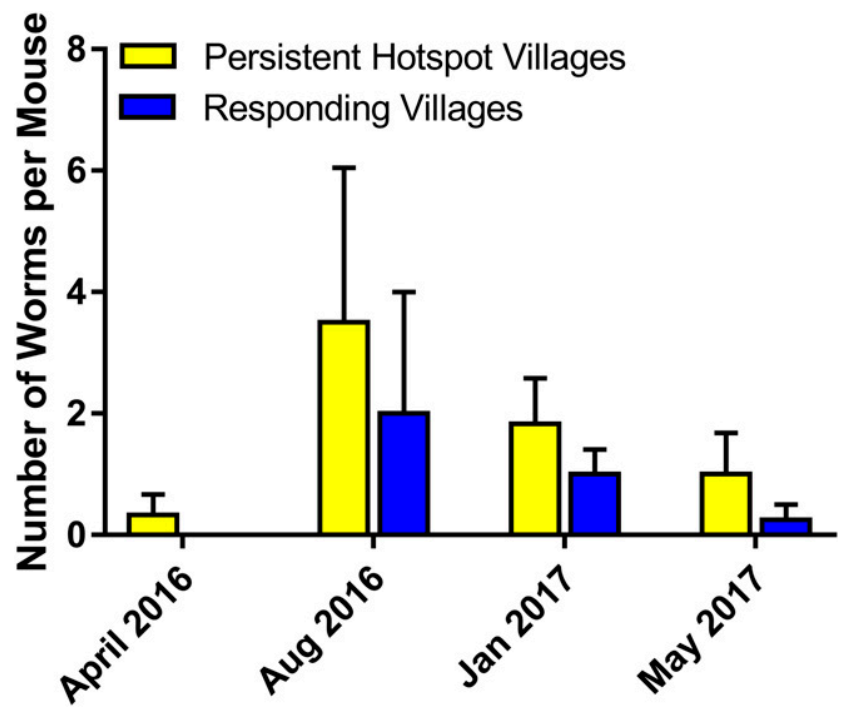

FIGURE 5. The total number of adult schistosomes collected from sentinel mice was greater in persistent hotspot than responding sites, but there was no statistical difference between them when village, hyacinths, and time point were considered. This figure appears in color at www.ajtmh.org.
Kotieno (Supplemental Table 1). All three villages had relatively high Biomphalaria populations and yielded the most S. mansoni infections found in snails relative to other villages (Table 2).

\section{DISCUSSION}

The SCORE-supported PZQ-based treatment program in the Lake Victoria region in western Kenya noted that PHS villages comprised approximately a third of the 150 study villages. The village prevalence was determined by testing 9-12-year-old students each year. These students had a relative risk of infection that was nearly four times higher than for students outside the PHS area. ${ }^{17}$ The SCORE program is by no means unique in identifying difficulties in reducing prevalence of infection in some villages adjacent to Lake Victoria. ${ }^{19}$ The PHS for S. mansoni transmission identified by Wiegand et al. ${ }^{17}$ was in Siaya County, Bondo region of western Kenya, associated with west-facing villages adjacent to the open, unprotected waters of the lake. By contrast, the PZQ RESP villages faced the more protected waters of the Winam Gulf.
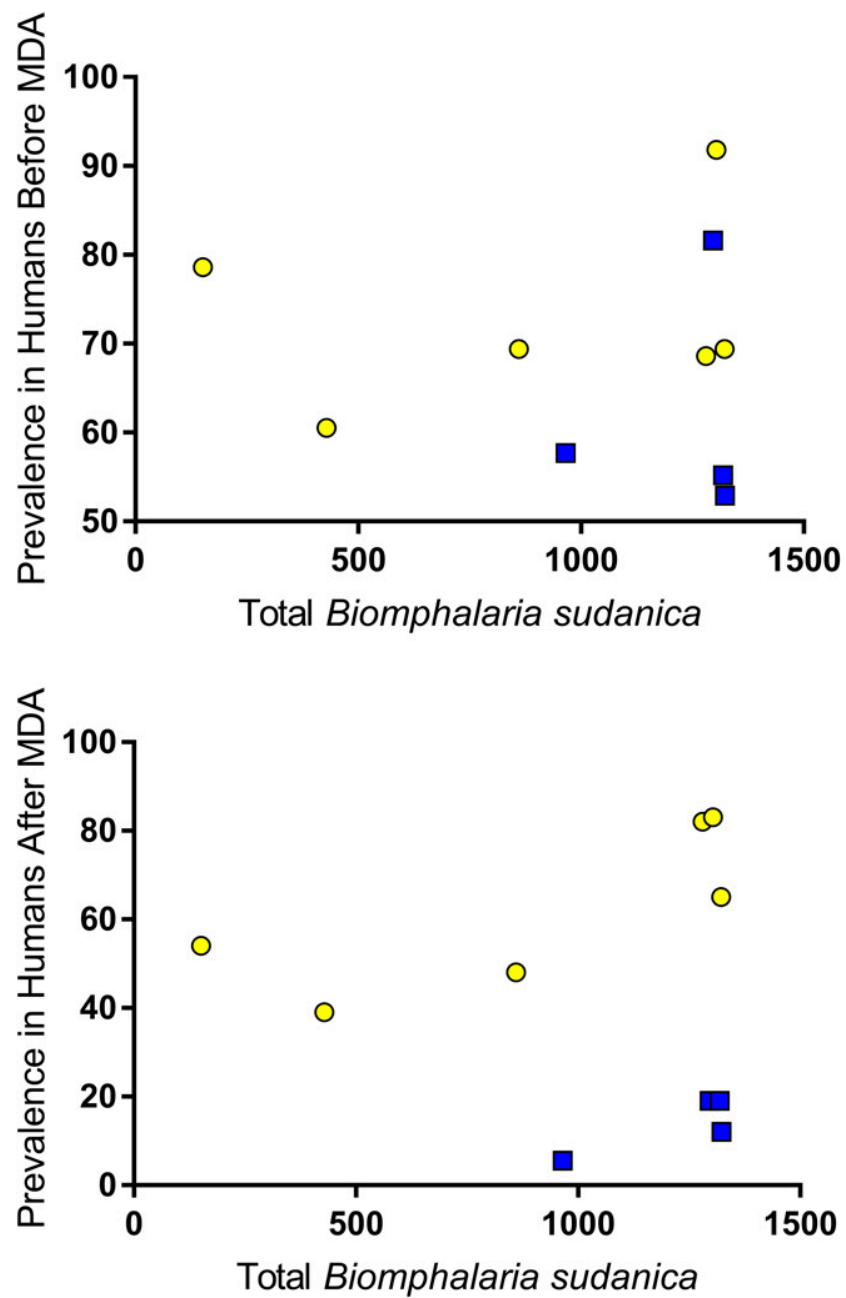

FIGURE 6. Total number of Biomphalaria sudanica collected at a village was not significantly correlated with the prevalence of Schistosoma mansoni in humans either before or after the drug treatment intervention (before: Pearson $r=-0.0369, P=0.460$; after: Pearson $r=-0.009, P=0.49$ ). Yellow $=$ persistent hotspot villages; blue $=$ responding villages. This figure appears in color at www.ajtmh.org. 

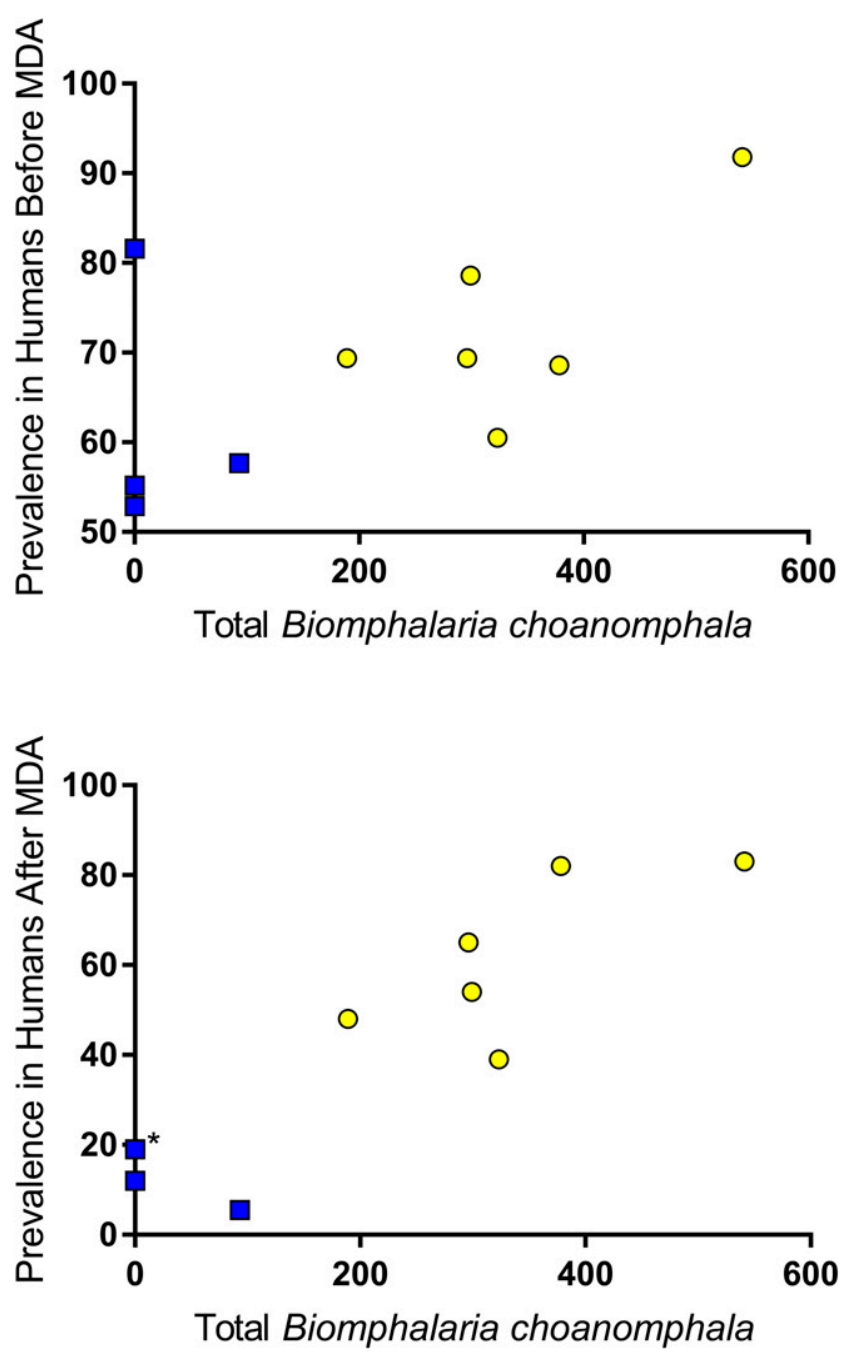

Figure 7. Total number of Biomphalaria choanomphala collected at a village was significantly correlated with the prevalence of Schistosoma mansoni in humans both before and after mass drug administration (before: Pearson $r=0.587, r^{2}=0.345, P=0.037$; after: Pearson $\left.r=0.9034, r^{2}=0.816, P=0.0002\right)$. Yellow $=$ persistent hotspot villages; blue $=$ responding villages ( ${ }^{*}$ two villages with same prevalence). This figure appears in color at www.ajtmh.org.

Among several factors postulated to be associated with the PHS we considered in our investigation, were larger snail populations or presence of different species of vector snail factors. $^{17}$

Of the three taxa of Biomphalaria commonly implicated in the transmission of $S$. mansoni in Kenya, two were collected in this study, the shoreline-associated taxon $B$. sudanica and the deeper water taxon $B$. choanomphala. There was no obvious indication that $B$. pfeifferi played a role in $S$. mansoni transmission in any of our study villages as no snails of this species were found in the lake or in streams or small impoundments within the study localities. We found $B$. sudanica at all 20 collecting sites, and it was typically abundant as it is along much of the Lake Victoria shoreline. ${ }^{9,11,21,33}$ We recovered approximately five times as many $B$. sudanica as B. choanomphala.

When taking into account all sampling sites, sampling times and presence of hyacinths, mean abundance of $B$. sudanica did not differ statistically between PHS and RESP villages.
We did note a significant trend for more $B$. sudanica to be present from our collecting sites if mats of hyacinths were present at the time we took our samples. Hyacinth mats were found in collecting sites from both PHS and RESP villages but were more common in the RESP villages located along the Winam Gulf, an area known to be prone to hyacinth intrusions. ${ }^{37}$ The recovery of $B$. sudanica from hyacinths and the association we noted for them with hyacinths supports the assertion that floating hyacinth mats favor the dispersal of $B$. sudanica along the lakeshore. ${ }^{34}$ Hyacinth movements are likely to have major effects on the population structure of $B$. sudanica in the lake.

By contrast, $B$. choanomphala was significantly more likely to be recovered from PHS than RESP villages. We found B. choanomphala from all 12 of the collecting sites in PHS villages and from only two of the eight collecting sites from RESP villages, both from the village of Mumbo. Mumbo is located closer to the mouth of the Winam Gulf than the remaining RESP villages, which are located in more protected waters of the gulf. Previous studies have also shown $B$. choanomphala to be rare or absent within the Winam Gulf, possibly because the bottom substrate is too muddy, whereas the substrate found off the shore of the PHS villages was a combination of sand and mud, known to be favorable to $B$. choanomphala. ${ }^{11,21}$ Gouvras et al. ${ }^{33}$ found $B$. choanomphala to be focally distributed in the Tanzanian waters of the lake, including in some more protected inlets. They noted, as did we, a general trend for this species to be more common in western than eastern locations and considered a possible gradual change in substratum conditions from west to east might be responsible. Many other factors such as levels of dissolved oxygen, pollution, and seasonal effects such as rainfall may also influence $B$. choanomphala populations. $^{32,33}$ We did not observe any association between the abundance of $B$. choanomphala and water hyacinths. Although hyacinth mats can cover areas of the lake where deeper water and hence $B$. choanomphala populations are present and could have adverse shading or other effects, our impression was that hyacinth mats along the more exposed shores away from the gulf were more prone to be dispersed by winds.

With respect to the schistosome infections among the snails recovered, a couple of caveats should be kept in mind. One is that some infections are prepatent at the time the snails are collected such that these infections would be missed. Our approach here was simply to retain all nonshedding snails in laboratory aquaria and to re-shed them after 4 weeks. This is because we have excellent snail-rearing facilities near our field sites at our disposal in which mortality of snails during the 4-week interval can be minimized. This approach has the advantage of detecting those infections that successfully transition to patency (cercariae are actually produced). An alternative approach to detect prepatent infections is to use molecular xenomonitoring techniques to detect nascent infections at the time of collection. ${ }^{23,27,33,47}$ Such techniques can be very sensitive and specific but are prone to error if the infection is very young at the time of assay, and some detected infections may be doomed to fail, so transmission potential could potentially be overestimated. ${ }^{27}$ Also, extractions of individual snails for PCR-based or other types of molecular detection of prepatent infections becomes prohibitively expensive and time-consuming when large numbers 
of snails need to be screened. Pooling of samples or use of eDNA-based techniques may help but are likely to be accompanied by a loss of precision in estimates of snail infection rates. ${ }^{48}$ The second caveat is that the rodenttransmitted S. rodhaini, the sister species of $S$. mansoni, is known to be present in the Lake Victoria basin, although it is rare by comparison with $S$. mansoni ${ }^{42}$ We extracted mammalian schistosome cercariae (four cercariae per infected snail) from 20 different positive snails, and all yielded nad5 bands consistent with $S$. mansoni, with one of these samples indicating a coinfection with S. rodhaini. ${ }^{27}$ Molecularly based techniques unquestionably increase the accuracy of species identifications but again pose some challenges insofar as an infected snail can produce thousands of cercariae over a period of several months, and it is conceivable that the species composition of the schistosome cercariae could change during the interval. Again, with a large survey with many positive snails recovered, resources limit the ability to repeatedly sample individual cercariae produced by the same snail. Acknowledging this constraint, given the ubiquity of human infections in our study area and that 20 of 20 positive snails cercariae samples we tested were identified as S. mansoni, we are confident the conclusions we reach here pertain to $S$. mansoni infections.

With these caveats in mind, for snail infections of S. mansoni, both the number of positive snails found and prevalence were higher for $B$. sudanica than $B$. choanomphala. The overall prevalence of $S$. mansoni infections in all the Biomphalaria snails collected was almost 2-fold higher for the PHS villages than for the RESP villages, and the highest recovery of positive snails was found in Kanyibok (1.57\%) and Usenge (1.42\%), two of the villages with the highest residual prevalence of infections in school children. However, one RESP village Kotieno also showed a high overall prevalence of infected snails (1.36\%). When all sampling sites, sampling times, and presence of hyacinths were taken into account, PHS and RESP villages did not differ with respect to numbers or prevalence of infected $B$. sudanica. The few $B$. choanomphala found to be positive were recovered only from PHS villages.

We also noted a suggestive negative relationship between hyacinth presence and infection rates of $B$. sudanica with $S$. mansoni. If a true association, this finding may reflect a decreased likelihood of collecting infected snails when large hyacinth mats are present. Several explanations could account for this, including higher mortality of infected snails due to oxygen depletion under hyacinth mats, reluctance of people to enter water for either defecation or washing purposes if hyacinths are present, or increased difficulty of miracidia in finding snails in spatially complex hyacinth mats. In general, the role of hyacinths in understanding the dynamics of schistosomiasis transmission in the lake requires further investigation.

Although fewer $B$. choanomphala than $B$. sudanica were collected and their prevalence of infection with S. mansoni was relatively low, it would be incorrect to assume the former species has limited significance with respect to schistosome epidemiology in Lake Victoria. Our dredge hauls across the extensive bottom surface of the lake can only be expected to retrieve a small proportion of the snails present and likely grossly underestimate the role of this snail species in perpetuating transmission. At least two factors might facilitate infections in $B$. choanomphala: currents moving from offshore to deeper water and fishermen who may defecate directly into deeper water from their boats. In this regard, failure to include fishermen in control programs may favor B. choanomphala-mediated transmission. Another factor potentially favoring involvement of $B$. choanomphala in transmission is that experimental infection studies of Kenyaderived specimens suggest this species, as with $B$. pfeifferi, is inherently more susceptible to S. mansoni than B. sudanica. ${ }^{28,30}$ Gouvras et al. ${ }^{33}$ working in southern Lake Victoria found more B. choanomphala positive for $S$. mansoni than we did: $12.2 \%$ of all $S$. mansoni shedders were $B$. choanomphala in their study versus only $3.5 \%$ in our study. In both studies, however, $B$. sudanica was identified as the major vector for S. mansoni in the lake.

Considering the second measure of the force of transmission we examined, namely sentinel mice infections, we did not observe a significant difference in mean number of worms recovered between PHS and RESP villages, although worm recoveries were approximately twice as high in the former and a positive correlation was noted across villages between the total number of snails shedding S. mansoni and the number of worms recovered from mice. Results of snail collections and worm recoveries were concordant in $60 \%$ of our 40 sampling times, but presence of $S$. mansoni-shedding snails by no means guaranteed the recovery of worms from sentinel mice placed nearby and vice versa: recovery of worms from sentinel mice was frequently noted at sampling locations and times we found no shedding snails. This suggests that neither method perfectly reflects the possibility of transmission at a particular locality at a certain time.

Not unexpectedly, and as reported from previous studies, Biomphalaria snails shedding other trematode cercariae were also frequently collected. ${ }^{49-52}$ Although non-schistosome infections exceeded S. mansoni infections by a factor of 2.9, we noted no significant positive or negative associations with any of the groups of trematodes with S. mansoni infections. The three villages that yielded the most $S$. mansoni snail infections (PHS villages Kanyibok and Usenge and RESP Kotieno) also yielded by far the most infections with other trematodes, suggesting they are general "trematode-transmitting hotspots." One possibility to explain this is that the overall susceptibility to trematode infection is higher in snails from collecting sites in some villages than others. This possibility is currently being examined with respect to susceptibility to S. mansoni. Another explanation is that certain water contact points along the lakeshore attract intense activity by a variety of potential definitive hosts, including people, domestic animals such as cattle or goats, and wild birds, the latter often thronging to locations where fishermen bring their catches. People often contact water extensively at such sites, making them potentially dangerous potential transmission sites.

In comparison with $B$. sudanica, $B$. choanomphala had fewer S. mansoni infections and fewer infections with trematodes of other species (only four other species noted). Deep water has been considered a refugium or in the parlance of King et al., ${ }^{52}$ a "coevolutionary cold spot" that limits exposure of snails to digenetic trematodes. In comparison, shoreline habitats are visited by numerous definitive hosts and can be considered as "coevolutionary hotspots" for digenetic trematode infections, supported by the many trematode species noted to be transmitted by $B$. sudanica. ${ }^{52}$ 
This study poses several questions requiring clarification. For instance, it might be argued that PHS villages have higher prevalence of human infections because the snails adjacent to such villages are more susceptible to $S$. mansoni infection. Experiments are underway to test the relative compatibility of $B$. sudanica from different villages to sympatric and allopatric isolates of $S$. mansoni. Our null hypothesis is that strongly differentiated patterns of schistosome-snail compatibility will not be seen because both human migration (and consequently S. mansoni migration) and snail movements mediated by hyacinths, winds, and currents will overcome local differentiation. Also, in need of additional clarification is the extent to which the gene pools of $B$. sudanica and $B$. choanomphala comingle. Studies of mitochondrial and nuclear markers indicate the two taxa are not highly divergent genetically and should probably be considered as a single species with the species name with precedence yet to be decided. ${ }^{12,13}$ It is clear, however, that pockets of snails with the characteristic $B$. choanomphala phenotype can be recovered from the shoreline over a period of several months. The extent to which snails of the two phenotypes interbreed, the appearance of the progeny, and the nature of genes and alleles dictating compatibility to schistosomes and other trematodes all remain to be investigated.

\section{CONCLUSION}

Results of this study did not find significant differences between PHS and RESP villages for $B$. sudanica with respect to relative abundance or numbers of snails shedding S. mansoni cercariae or in the number of worms recovered from sentinel mice. Although $B$. sudanica was present in all the villages we studied and based on the number of positive snails of this species recovered is also the major vector for $S$. mansoni in all villages, $B$. choanomphala was found in all PHS villages and in only one RESP village. The relative abundance of $B$. choanomphala was significantly higher in PHS villages. In our view, $B$. choanomphala may provide an under-appreciated and more diffuse and difficult-to-measure alternative route of transmission along much of the shore of the lake. Many other trematode species infect Biomphalaria snails in Lake Victoria, but their overall prevalence is low and suggests they do not have a dramatic primary effect on S. mansoni prevalence rates in snails. Evidence of active S. mansoni transmission was found in all 10 villages investigated, not surprising from the standpoint that the lake supports massive populations of Biomphalaria snails and sanitary facilities in rural areas around the lake are scarce. However, distinct differential responsiveness to annual MDA with PZQ was somewhat surprising. Nevertheless, opportunities for transmission and reinfections are very likely to continue to occur, even in RESP villages. Control of S. mansoni in and around the lake will remain a daunting challenge, and its persistence argues more persuasively than ever for implementation of improved sanitation and provision of safe water supplies as important parts of an integrated and sustained three-country basin-wide control approach and as fundamental rights for the people living in the area.

Received January 29, 2019. Accepted for publication April 16, 2019.

Published online June 3, 2019.

Note: Supplemental table appears at www.ajtmh.org.
Acknowledgments: We thank Stephen Munga, Director, Center for Global Health Research, Kenya Medical Research Institute (KEMRI), for providing laboratory space to carry out the study and Joseph Kinuthia, Geoffrey Maina, Polycarp Oraro, and Boaz Oduor for their technical assistance in the laboratory and field sampling. Daniel G. Colley, Nupur Kittur, and other members of the SCORE secretariat provided several invaluable comments. This research was undertaken with the approvals of the National Commission for Science, Technology and Innovations (permit number P/16/9609/12754) and the National Environmental Management Authority (permit number NEMA/AGR/46/2014). Field sampling of snails in the habitats was done under authorization from the Kenya Wildlife Service (permit number KWS/BRM/5001). This paper is published with the approval of the Director, KEMRI.

Financial support: This study was supported by the University of Georgia Research Foundation Inc., which was funded by the Bill \& Melinda Gates Foundation for the SCORE project and the National Institutes of Health grants numbered R37Al101438, 1R01Al141862, and P30GM110907, and The Fogarty International Center and National Institute of Mental Health, NIH award number D43 TW010543.

Authors' addresses: Martin W. Mutuku, Centre for Biotechnology Research and Development, Kenya Medical Research Institute, Nairobi, Kenya, and School of Biological Sciences, College of Biological and Physical Sciences, University of Nairobi, Nairobi, Kenya, E-mails: mmutuku@kemri.org or mwmutuku81@gmail.com. Martina R. Laidemitt, Bishoy Kamel, and Eric S. Loker, Department of Biology, Center for Evolutionary and Theoretical Immunology, Museum of Southwestern Biology, Parasitology Division, University of New Mexico, Albuquerque, NM, E-mails: mlaidemitt@unm.edu, bishoyh@ unm.edu, and esloker@unm.edu. Brianna R. Beechler, Department of Biomedical Sciences, College of Veterinary Medicine, Oregon State University, Corvallis, OR, E-mail: breebeechler@gmail.com. Ibrahim N. Mwangi, Eric L. Agola, and Gerald M. Mkoji, Centre for Biotechnology Research and Development, Kenya Medical Research Institute, Nairobi, Kenya, E-mails: indungu@kemri.org, elelo@ kemri.org, and gmkoji5@gmail.com. Fredrick O. Otiato, Influenza Surveillance Program, Centers for Disease Control and Prevention, Nairobi, Kenya, E-mail: frede516@gmail.com. Horace Ochanda, School of Biological Sciences, College of Biological and Physical Sciences, University of Nairobi, Nairobi, Kenya, E-mail: hochanda@ uonbi.ac.ke. Michelle L. Steinauer, Department of Basic Medical Sciences, Western University of Health Sciences, Lebanon, OR, E-mail: msteinauer@westernu.edu.

This is an open-access article distributed under the terms of the Creative Commons Attribution License, which permits unrestricted use, distribution, and reproduction in any medium, provided the original author and source are credited.

\section{REFERENCES}

1. Colley DG, Bustinduy AL, Secor WE, King CH, 2014. Human schistosomiasis. Lancet 383: 2253-2264.

2. Rollinson $D$ et al., 2013. Time to set the agenda for schistosomiasis elimination. Acta Trop 128: 423-440.

3. King $\mathrm{CH}, 2015$. Health metrics for helminth infections. Acta Trop 141: 150-160.

4. King $\mathrm{CH}$, Dangerfield-Cha M, 2008. The unacknowledged impact of chronic schistosomiasis. Chronic IIIn 4: 65-79.

5. Webster JP, Molyneux DH, Hotez PJ, Fenwick A, 2014. The contribution of mass drug administration to global health: past, present and future. Philos Trans $R$ Soc Lond B Biol Sci 369: 20130434.

6. Sokolow SH, Wood CL, Jones IJ, Swartz SJ, Lopez M, Hsieh MH, Lafferty KD, Kuris AM, Rickards C, De Leo GA, 2016. Global assessment of schistosomiasis control over the past century shows targeting the snail intermediate host works best. PLOS Negl Trop Dis 10: e0004794.

7. Ross AG, Chau TN, Inobaya MT, Olveda RM, LiY, Harn DA, 2017. A new global strategy for the elimination of schistosomiasis. Int J Infect Dis 54: 130-137.

8. Hotez PJ, Kamath A, 2009. Neglected tropical diseases in subSaharan Africa: review of their prevalence, distribution, and disease burden. PLoS Negl Trop Dis 3: e412. 
9. Brown DS, 1994. Freshwater Snails of Africa and Their Medical Importance, 2nd edition. London, United Kingdom: Taylor and Francis Limited, 609.

10. Dejong RJ et al., 2001. Evolutionary relationships and biogeography of Biomphalaria (Gastropoda: Planorbidae) with implications regarding its role as host of the human bloodfluke, Schistosoma mansoni. Mol Biol Evol 18: 2225-2239.

11. Loker ES, Hofkin BV, Mkoji GM, Mungai B, Kihara J, Koech DK, 1993. Distributions of freshwater snails in southern Kenya with implications for the biological control of schistosomiasis and other snail-mediated parasites. J Med Appl Malacol 5: 1-20.

12. Standley CJ, Wade CM, Stothard JR, 2011. A fresh insight into transmission of schistosomiasis: a misleading tale of Biomphalaria in Lake Victoria. PLoS One 6: e26563.

13. Zhang SM, Bu L, Laidemitt MR, Lu L, Mutuku MW, Mkoji GM, Loker ES, 2018. Complete mitochondrial and rDNA complex sequences of important vector species of Biomphalaria, obligatory hosts of the human-infecting blood fluke, Schistosoma mansoni. Sci Rep 8: 7341.

14. Available at: http://www.thiswormyworld.org/maps/distributionof-s-mansoni-survey-data-in-kenya.

15. Odiere MR, Rawago FO, Ombok M, Secor WE, Karanja DM, Mwinzi PN, Lammie PJ, Won K, 2012. High prevalence of schistosomiasis in Mbita and its adjacent islands of Lake Victoria, western Kenya. Parasit Vectors 5: 278.

16. Samuels AM, Matey E, Mwinzi PN, Wiegand RE, Muchiri G, Ireri E, Hyde M, Montgomery SP, Karanja DM, Secor WE, 2012. Schistosoma mansoni morbidity among school-aged children: a SCORE project in Kenya. Am J Trop Med Hyg 87: 874-882.

17. Wiegand RE et al., 2017. A persistent hotspot of Schistosoma mansoni infection in a five-year randomized trial of praziquantel preventative chemotherapy strategies. J Infect Dis 216: 1425-1433.

18. Kabatereine NB, Brooker S, Koukounari A, Kazibwe F, Tukahebwa EM, Fleming FM, Zhang Y, Webster JP, Stothard JR, Fenwick A, 2007. Impact of a national helminth control programme on infection and morbidity in Ugandan schoolchildren. Bull World Health Organ 85: 91-99.

19. Crellen T, Walker M, Lamberton $\mathrm{PH}$, Kabatereine NB, Tukahebwa EM, Cotton JA, Webster JP, 2016. Reduced efficacy of praziquantel against Schistosoma mansoni is associated with multiple rounds of mass drug administration. Clin Infect Dis 63: 1151-1159.

20. Olsen A, Kinung'hi S, Magnussen P, 2018. Comparison of the impact of different mass drug administration strategies on infection with Schistosoma mansoni in Mwanza region, Tanzania-a cluster-randomized controlled trial. Am J Trop Med Hyg 99: 1573-1579.

21. Magendantz M,1972. The biology of Biomphalaria choanomphala and $B$. sudanica in relation to their role in the transmission of Schistosoma mansoni in Lake Victoria at Mwanza, Tanzania. Bull World Health Organ 47: 331-341.

22. Kabatereine NB, Kazibwe F, Kemijumbi J, 1996. Epidemiology of schistosomiasis in Kampala, Uganda. East Afr Med $J$ 73: 795-800.

23. Standley CJ, Kabatereine NB, Lange CN, Lwambo NJ, Stothard $\mathrm{JR}, 2010$. Molecular epidemiology and phylogeography of Schistosoma mansoni around Lake Victoria. Parasitology 137: 1937-1949.

24. Grimes JE, Croll D, Harrison WE, Utzinger J, Freeman MC, Templeton MR, 2015. The roles of water, sanitation and hygiene in reducing schistosomiasis: a review. Parasit Vectors 8: 156.

25. Frandsen F, 1979. Studies of the relationship between Schistosoma and their intermediate hosts. III. The genus Biomphalaria and Schistosoma mansoni from Egypt, Kenya, Sudan, Uganda, West Indies (St. Lucia) and Zaire (two different strains: Katanga and Kinshasa). J Helminthol 53: 321-348.

26. Adriko M, Standley CJ, Tinkitina B, Mwesigwa G, Kristensen TK, Stothard JR, Kabatereine NB, 2013. Compatibility of Ugandan Schistosoma mansoni isolates with Biomphalaria snail species from Lake Albert and Lake Victoria. Acta Trop 128: 303-308.

27. Lu L, Zhang SM, Mutuku MW, Mkoji GM, Loker ES, 2016. Relative compatibility of Schistosoma mansoni with Biomphalaria sudanica and $B$. pfeifferi from Kenya as assessed by PCR amplification of the S. mansoni ND5 gene in conjunction with traditional methods. Parasit Vectors 9: 166.

28. Mutuku MW et al., 2017. A comparison of Kenyan Biomphalaria pfeifferi and B. sudanica as vectors for Schistosoma mansoni, including a discussion of the need to better understand the effects of snail breeding systems on transmission. $J$ Parasitol 103: 669-676.

29. Tavalire HF, Blouin MS, Steinauer ML, 2016. Genotypic variation in host response to infection affects parasite reproductive rate. Int J Parasitol 46: 123-131.

30. Mutuku MW et al., 2014. Field-derived Schistosoma mansoni and Biomphalaria pfeifferi in Kenya: a compatible association characterized by lack of strong local adaptation, and presence of some snails able to persistently produce cercariae for over a year. Parasit Vectors 7: 533.

31. Standley CJ, Vounatsou P, Gosoniu L, Jørgensen A, Adriko M, Lwambo NJS, Lange CN, Kabatereine NB, Stothard JR, 2012. The distribution of Biomphalaria (Gastropoda: Planorbidae) in Lake Victoria with ecological and spatial predictions using Bayesian modelling. Hydrobiologia 683: 249-264.

32. Lange CN, Kristensen TK, Madsen H, 2013. Gastropod diversity, distribution and abundance in habitats with and without anthropogenic disturbances in Lake Victoria, Kenya. Afr J Aquat Sci 38: 295-304.

33. Gouvras AN, Allan F, Kinung'hi S, Rabone M, Emery A, Angelo T, Pennance T, Webster B, Nagai H, Rollinson D, 2017. Longitudinal survey on the distribution of Biomphalaria sudanica and $B$. choanomophala in Mwanza region, on the shores of Lake Victoria, Tanzania: implications for schistosomiasis transmission and control. Parasit Vectors 10: 316.

34. Coles GC, Kabatereine NB, 2008. Water hyacinth and the transmission of schistosomiasis. Trans $R$ Soc Trop Med Hyg 102: 619-620.

35. Plummer ML, 2005. Impact of invasive water hyacinth (Eichhornia crassipes) on snail hosts of schistosomiasis in Lake Victoria, East Africa. EcoHealth 2: 81-86.

36. Ofulla AVO, Karanja D, Omondi R, Okurut T, Matano A, Jembe T, Abila R, Boera P, Gichuki J, 2010. Relative abundance of mosquitoes and snails associated with water hyacinth and hippo grass in the Nyanza gulf of Lake Victoria. Lakes Reservoirs 15: 255-271.

37. Opande GO, Onyango JC, Wagai SO, 2004. Lake Victoria: the water hyacinth (Eichhornia crassipes [Mart.] Solms), its socioeconomic effects, control measures and resurgence in the Winam Gulf. Limnologica 34: 105-109.

38. Kittur N, Binder S, Campbell CH, King CH, Kinung'hi S, Olsen A, Magnussen P, Colley DG, 2017. Defining persistent hotspots: areas that fail to decrease meaningfully in prevalence after multiple years of mass drug administration with praziquantel for control of schistosomiasis. Am J Trop Med Hyg 97: 1810-1817.

39. Kristensen TK, 1987. A Field Guide to African Freshwater Snails. East African Species, 2nd edition. Charlottenlund, Denmark: Danish Bilharziasis Laboratory.

40. Frandsen F, Christensen NO, 1984. An introductory guide to the identification of cercariae from African freshwater snails with special reference to cercariae of trematode species of medical and veterinary importance. Acta Trop 41: 181-202.

41. Laidemitt MR, Zawadzki ET, Brant SV, Mutuku MW, Mkoji GM, Loker ES, 2017. Loads of trematodes: discovering hidden diversity of paramphistomoids in Kenyan ruminants. Parasitology 144: 131-147.

42. Steinauer ML, Mwangi IN, Maina GM, Kinuthia JM, Mutuku MW, Agola EL, Mungai B, Mkoji GM, Loker ES, 2008. Interactions between natural populations of human and rodent schistosomes in the Lake Victoria region of Kenya: a molecular epidemiological approach. PLoS Negl Trop Dis 2: e222.

43. Yolles TK, Moore DV, DeGiusti DL, Ripsom CA, Meleney HE, 1947. A technique for the perfusion of laboratory animals for the recovery of schistosomes. J Parasitol 33: 419-426.

44. Brooks ME, Kristensen K, Van Benthem KJ, Magnusson A, Berg CW, Nielsen A, Skaug HJ, Maechler M, Bolker BM, 2017. glmmTMB balances speed and flexibility among packages for zero-inflated generalized linear mixed modeling. $R$ J 9: 378-400. 
45. Bates D, Maechler M, Bolker B, Walker S, 2015. Fitting linear mixed-effects models using Ime4. J Stat Softw 67: 1-48.

46. Gelman A, 2008. Scaling regression inputs by dividing by two standard deviations. Stat Med 27: 2865-2873.

47. Abbasi I, King CH, Muchiri EM, Hamburger J, 2010. Detection of Schistosoma mansoni and Schistosoma haematobium DNA by loop-mediated isothermal amplification: identification of infected snails from early prepatency. Am J Trop Med Hyg 83: $427-432$.

48. Sato MO et al., 2018. Usefulness of environmental DNA for detecting Schistosoma mansoni occurrence sites in Madagascar. Int J Infect Dis 76: 130-136.

49. Rowel C, Fred B, Betson M, Sousa-Figueiredo JC, Kabatereine NB, Stothard JR, 2015. Environmental epidemiology of intestinal schistosomiasis in Uganda: population dynamics of Biomphalaria (Gastropoda: Planorbidae) in Lake Albert and Lake Victoria with observations on natural infections with digenetic trematodes. Biomed Res Int 2015: 717261.

50. Okeke OC, Ubachukwu PO, 2017. Trematode infections of the freshwater snail Biomphalaria pfeifferi from a south-east Nigerian community with emphasis on cercariae of Schistosoma. J Helminthol 91: 295-301.

51. Mohammed NA, Madsen H, Ahmed AA, 2016. Types of trematodes infecting freshwater snails found in irrigation canals in the East Nile locality, Khartoum, Sudan. Infect Dis Poverty 5: 16.

52. King KC, Delph LF, Jokela J, Lively CM, 2009. The geographic mosaic of sex and the Red Queen. Curr Biol 19: 1438-1441. 